PEMBELAJAR: Jurnal Ilmu Pendidikan, Keguruan, dan Pembelajaran

Volume 1 Nomor 2 Oktober 2017 Hal. 65- 68

e-ISSN: 2549-9114 dan p-ISSN: 2549-9203

(Received: Agustus -2017; Reviewed: September -2017; Published: Oktober 2017)

\title{
PERANAN GURU BK DALAM MEMBENTUK KARAKTER SISWA MELALUI LAYANAN BK KELOMPOK
}

\author{
Misrawati \\ Bimbingan dan Konseling, Universitas Negeri Makassar \\ Corresponding Email : misrawati50@gmail.com .
}

\begin{abstract}
Abstrak: Keberadaan guru bimbingan dan konseling disekolah memiliki peranan penting untuk membentuk karakter siswa, membantu setiap permasalahan yang dialami siswa, serta memilki tugas untuk mengembangkan aspek psikologis dan sosial siswa. Karakter adalah sifat atau watak yang ada pada diri seseorang yang bersifat unik yang dimiliki setiap orang sebagai akibat dari pola perilaku, norma-norma, dan moral yang terbentuk secara positif. Dalam aspek pendidikan karakter, semua yang dilakukan sebenarnya berada pada ranah afektif dan psikomotorik yang bersentuhan dengan pendidikan karakter tersebut. Peningkatan layanan bimbingan konseling di sekolah dalam hal ini layanan BK kelompok merupakan salah satu bentuk kegiatan pendidikan untuk pencapaian tujuan pendidikan nasional.
\end{abstract}

Kata kunci : Peranan Guru Bk, Karakter Siswa, dan Layanan BK Kelompok.

\begin{abstract}
The existence of guidance and counseling teachers in schools have an important role to shape the character of students, helping any problems experienced by the students, and have the task of developing psychological and social aspects of students. Character is the nature or character of oneself that is unique to everyone as a result of a pattern of behavior, norms and morals that formed positively. In the aspect of character education, all that does is actually located on the affective and psychomotor contact with the character education. Improved guidance and counseling services in schools in this group bk services is one form of educational activities for the achievement of national education goals.
\end{abstract}

Keywords: BK role of the teacher, the student's character, and service groups BK 


\section{PENDAHULUAN}

Pendidikan merupakan salah satu faktor yang sangat penting artinya dalam kehidupan berbangsa dan bernegara, kemajuan suatu bangsa sangat ditentukan oleh kemajuan pendidikan bangsa itu. Dalam era globalisasi yang terjadi saat ini membawa dampak yang sangat besar bagi masyarakat indonesia terutama mengenai pendidikan karakter bangsa. Arus informasi begitu deras masuk dari berbagai macam media, yang mana arus informasi ini tidak ada penyaringannya sehingga semua manusia bisa bebas mengaksesnya tanpa batas usia, seperti media Televisi, Media Massa dan Internet. Arus informasi tersebut semakin lama membuat cara pandang dan perilaku masyarakat sedikit demi sedikit berubah meninggalkan perilaku asli leluhur bangsa Indonesia. Perubahan ini sangat terasa dalam kehidupan sehari-hari terutama di sekolah seperti masih banyak siswa yang tidak menghormati guru, tidak disiplin, suka membolos, sering terlambat masuk kelas, tidak mengerjakan PR, merokok, narkoba, bullying dan lain sebagainya. Oleh karena itu perlu adanya peran Guru BK untuk membentuk karakter siswa melalui layanan BK Kelompok.

Guru BK mempunyai tugas dalam membentuk karakter siswa, peran layanan bimbingan kelompok diantaranya untuk membekali siswa dengan berbagai pengetahuan dan pemahaman tentang berbagai hal yang berguna untuk mengenal diri, merencanakan dan mengembangkan pola kehidupan sebagai pelajar, anggota keluarga, dan masyarakat. Pemahaman yang diperoleh melalui bimbingan kelompok ini digunakan sebagai bahan acuan untuk meningkatkan pendidikan karakter siswa. Dengan demikian, layanan bimbingan dan konseling di sekolah merupakan salah satu bentuk kegiatan pendidikan untuk pencapaian tujuan pendidikan. Sejalan dengan pengertian bimbingan dan konseling kelompok di atas, dilihat dari fungsinya, sekalipun tidak secara tegas dapat dipisahkan, dapat disimpulkan bahwa orientasi bimbingan kelompok lebih mengarah pada upaya pencegahan terjadinya suatu masalah, sekaligus mengandung fungsi pemeliharaan dan pengembangan. Sementara itu, konseling kelompok lebih berorientasi pada upaya pengentasan suatu masalah. Sekalipun orientasi utama pada pengentasan masalah, akan tetapi tidak berarti, proses pencegahan terjadinya masalah, tidak menjadi sasaran dari layanan konseling kelompok. Guru bimbingan konseling berperan penting dalam membentuk karakter siswa. Penyelenggaraan pendidikan karakter memerlukan pendekatan personal, baik dalam arti guru pembimbing harus kompeten dan layak untuk dicontoh, disamping itu juga pada umumnya para siswa akan "respek" kepada mereka yang memiliki kedekatan secara pribadi sehingga memudahkan terjadinya penyampaian pesan-pesan atau informasi tentang pendidikan karakter. Salah satu cara yang bisa ditempuh oleh Guru BK yaitu dengan menyelenggarakan layanan bimbingan dan konseling kelompok.

\section{PEMBAHASAN}

\subsection{Pendidikan Karakter}

Karakter adalah sifat pribadi yang relatif stabil pada diri individu yang menjadi landasan bagi penampilan perilaku dalam standar nilai dan norma yang tinggi (Prayitno, Belferik M, 2010). Pendapat lain menyatakan karakter atau watak pada hakekatnya merupakan ciri kepribadian yang berkaitan dengan timbangan nilai moralitas normatif yang berlaku (Mohamad Surya, 2012). Karakter diartikan sebagai sifat manusia pada umumnya yang bergantung pada faktor kehidupannya sendiri. Karakter merupakan nilai-nilai perilaku manusia yang berhubungan dengan Tuhan Yang Maha Esa, diri sendiri, sesama manusia, lingkungan, dan kebangsaan, yang terwujud dalam pikiran, sikap, perasaan, perkataan dan perbuatan berdasarkan norma-norma agama, hukum, tata krama, budaya dan adat istiadat (Agus Zaenul Fitri, 2012: 20). Kualitas watak seseorang bersifat relatif tetap dan akan tercermin pada penampilan kepribadiannya ditinjau dari sudut timbangan nilai moral normatif. Atribut utama karakter yang perlu dikembangkan adalah tercapainya karakter dengan kualitas : 1) memiliki courage atau keberanian dalam melaksanakan tindakan, 2) care atau memiliki kepedulian terhadap tugasnya, 3) optimistik terhadap masa depan, 4) self control atau kemampuan mengendalikan diri dalam melaksanakan tugas, dan 5) communication atau kemampuan berkomunikasi efektif dalam keseluruhan pemberian pelayanan. Pembentukan dan pengembangan karakter manusia dapat dicapai melalui proses pendidikan. 
Pendidikan karakter secara sederhana dapat dimaknai sebagai pendidikan yang menjadikan karakter sebagai bagian yang mewarnai proses pendidikan. Karakter itu sendiri merupakan nilai-nilai yang melandasi perilaku manusia berdasarkan norma agama, kebudayaan, hukum/konstitusi, adat istiadat dan estetika. Pendidikan karakter merupakan upaya yang terencana untuk menjadikan peserta didik mengenal, peduli dan menginternalisasi nilai-nilai sehingga peserta didik berperilaku sebagai insan kamil, dengan demikian pendidikan karakter merupakan suatu system penanaman nilai-nilai perilaku (karakter) kepada peserta didik yang meliputi komponen pengetahuan (knowledge), kesadaran atau kemauan, dan tindakan untuk melaksanakan nilai-nilai baik terhadap Tuhan Yang Maha Esa, diri sendiri, sesame, lingkungan, maupun kebangsaan sehingga menjadi manusia insan kamil (Kemendiknas, 2010).

\subsection{Bimbingan Konseling Kelompok}

Bimbingan Kelompok merupakan salah satu teknik bimbingan yang berusaha membantu individu agar dapat mencapai perkembangannya secara optimal sesuai dengan kemampuan, bakat, minat, serta nilainilai yang dianutnya, dan dilaksanakan dalam situasi kelompok. Bimbingan kelompok bersifat pencegahan dan pengambangan dan berorientasi pada pencapaian tujuan. Bentuk kegiatan kelompok yang lebih intensif yang bersifat perbaikan dan penyembuhan yang menekankan pada perubahan perilaku dan kepribadian dikenal dengan nama konseling kelompok dan psikoterapi kelompok. Sedangkan konseling kelompok merupakan salah satu layanan konseling yang di selenggarakan dalam suasana kelompok yang memanfaatkan dinamika kelompok, serta terdapat hubungan konseling yang hangat, terbuka, permisif dan penuh keakraban. Hal ini merupakan upaya individu untuk membantu individu agar dapat menjalani perkembangannya dengan lebih lancar, upaya itu bersifat preventif dan perbaikan karena pada konseling kelompok juga ada pengungkapan dan pemahaman masalah klien, penelusuran sebab-sebab timbulnya masalah, upaya pemecahan masalah, kegiatan evaluasi dan tindak lanjut.

\subsection{Peran Konselor Dalam Pendidikan Karakter}

Pendidikan karakter merupakan tugas bersama dalam mencapai peningkatan capaian karakter. Dua indikator pencapaian karakter, yaitu pada level individu siswa dan institusi pendidikan. Keberhasilan program pendidikan karakter dapat diketahui melalui pencapaian indikator oleh siswa sebagaimana tercantum dalam Standar Kompetensi Lulusan, yang antara lain meliputi sebagai berikut:

1. Mengamalkan ajaran agama yang dianut sesuai dengan tahap perkembangan remaja.

2. Memahami kekurangan dan kelebihan diri sendiri.

3. Menunjukkan sikap percaya

4. Mematuhi aturan -aturan sosial yang berlaku dalam lingkungan yang lebih luas.

5. Menghargai keberagaman agama, budaya, suku, ras, dan golongan sosial ekonomi dalam lingkup nasional.

6. Mencari dan menerapkan informasi dari lingkungan sekitar dan sumber -sumber lain secara logis, kritis, dan kreatif.

7. Menunjukkan kemampuan berpikir logis, kritis, kreatif, dan inovatif;Menunjukkan kemampuan belajar secara mandiri sesuai dengan potensi yang dimilikinya.

8. Menunjukkan kemampuan menganalisis dan memecahkan masalah dalam kehidupan sehari-hari.

9. Mendeskripsikan gejala alam dan social, memanfaatkan lingkungan secara bertanggung jawab.

10. Menerapkan nilai-nilai kebersamaan dalam kehidupan bermasyarakat, berbangsa, dan bernegara demi terwujudnya persatuan dalam negara kesatuan Republik Indonesia.

Kriteria pencapaian pendidikan karakter adalah terbentuknya budaya sekolah, yaitu perilaku, tradisi, kebiasaan keseharian, dan simbol -simbol yang dipraktikkan oleh semua warga sekolah, dan masyarakat sekitar sekolah harus berlandaskan nilai -nilai tersebut. Di dalam rambu-rambu penyelenggaraan bimbingan dan konseling dalam jalur pendidikan formal (Dep diknas, 2007) dijelaskan bahwa pelayanan ahli bimbingan dan konseling yang diampu oleh guru bk berada dalam konteks tugas "kawasan pelayanan yang bertujuan memandirikan siswa (individu) dalam memandu perjalanan hidup mereka melalui pengambilan keputusan, 
memilih, meraih serta mempertahankan karir. Terkait dengan kegiatan pendidikan karakter di sekolah, guru bk wajib memfasilitasi pengembangan dan penumbuhan karakter serta tanpa mengabaikan penguasaan hard skills lebih lanjut yang diperlukan dalam perjalanan hidup serta dalam mempersiapkan karier. Oleh karena itu, guru bk hendaknya merancangkan dalam program kegiatannya untuk secara aktif berpartisipasi dalam pengembangan dan penumbuhan karakter pada siswa.

\section{SIMPULAN}

Pelaksanaan layanan bimbingan dan konseling kelompok yang di laksanakan oleh guru BK memiliki peranan penting untuk membentuk karakter siswa di sekolah. Guru BK harus menyiapkan diri untuk melakukan koordinasi dan sinkronisasi sebagai bentuk sinergi pelaksanaan pendidikan karakter. Guru BK hendaknya mengembangkan nilai-nilai pendidikan karakter melalui kegiatan konseling yang dilakukannya. Tujuan dari pendidikan karakter adalah mengetahui, memahami, dan mengembangkan karakter yang positif. Sehingga mampu mewujudkan perilaku siswa yang memiliki kepribadian yang khas yang berkembang sesuai dengan nilai-nilai dan morma-norma agama serta bangsa.

\section{DAFTAR PUSTAKA}

Muslich, Masnur. (2013). PENDIDIKAN KARAKTER Menjawab Tantangan Krisis Multidimensional. Jakarta : Bumi Aksara.

Prayitno.(1995). Layanan Bimbingan dan Konseling Kelompok. Jakarta : Ghalia Indonesia.

Redjeki,Sri.(2013).Pengembangan Karakter Melalui Pelayanan Bimbingan dan Konseling. Semarang: FIP IKIP Veteran.

Roshita, Ita.(2015). Upaya Meningkatkan Perilaku Sopan Santun Melalui Layanan Bimbingan Kelompok Dengan Teknik Sosiodrama. Jawa Tengah : Jurnal Penelitian Tindakan Bimbingan dan Konseling

W. S. Winkel dan M.M. Sri Hastuti. 2004. Bimbingan Dan Konseling Di Institusi Pendidikan. Yogyakarta: Media Abadi. 